\title{
Theranostic approach for the protein corona of polysaccharide nanoparticles.
}

\author{
SKALICKOVA, S., HORKY, P., MLEJNKOVA, V., SKLADANDA, J., \\ HOSNEDLOVA, B., RUTTKAY-NEDECKY, B., FERNANDEZ, C. and KIZEK, R.
}

This is the peer reviewed version of the following article: SKALICKOVA, S., HORKY, P., MLEJNKOVA, V., SKLADANDA, J., HOSNEDLOVA, B., RUTTKAY-NEDECKY, B., FERNANDEZ, C. and KIZEK, R. 2021. Theranostic approach for the protein corona of polysaccharide nanoparticles. Chemical record [online], 21(1), pages 17-28, which has been published in final form at https://doi.org/10.1002/tcr.202000042. This article may be used for non-commercial purposes in accordance with the Wiley Self-Archiving Policy. 


\section{Theranostic Approach for the Protein Corona of \\ Polysaccharide Nanoparticles}

\author{
Sylvie Skalickova ${ }^{[a, b]}$, Pavel Horky ${ }^{[b]}$, Veronika \\ Mlejnkova ${ }^{[b]}$, Jiri Skladanka ${ }^{[b]}$, Bozena \\ Hosnedlova ${ }^{[c]}$, Branislav Ruttkay-Nedecky ${ }^{[c, d]}$, \\ Carlos Fernandez ${ }^{[\mathrm{e}]}$, Rene Kizek ${ }^{*}[\mathrm{a}, \mathrm{c}, \mathrm{f}]$
}

\begin{abstract}
Polysaccharide nanoparticles are promising materials in the wide range of disciplines such as medicine, nutrition, food production, agriculture, material science and others. They excel not only in their non-toxicity and biodegradability properties but also in their easy preparation. As well as inorganic particles, a protein corona (PC) around polysaccharide nanoparticles is formed in biofluids. Moreover, it has been considered that the overall response of the organism to nanoparticles presence depends on the PC. This review summarises scientific publications about the structural chemistry of polysaccharide nanoparticles and their impact on theranostic applications. Three strategies of implementation of the PC in theranostics have been discussed: I) Utilisation of the PC in therapy; II) How the composition of the PC is analysed for specific disease markers; III) How the formed PC can interact with the immune system and enhances the immunomodulation or immunoelimination. Thus, the findings from this review can contribute to improve the design of drug delivery systems. However, it is still necessary to elucidate the mechanisms of nano-bio interactions and discover new connections in nanoscale research.
\end{abstract}

\section{Introduction}

Nanotechnology is a rapidly developing area in science. Currently, it is becoming involved in medical disciplines such as disease diagnostics (e.g., cancer), vaccination, disease prevention,

[a] S. Skalickova, R. Kizek

Department of Pharmacology and Toxicology, Faculty of Pharmacy, Masaryk University , Palackeho 1946/1, 61200 Brno, Czech Republic

E-mail address: kizek@sci.muni.cz (R. Kizek), Telephone: +420 54156 2896, Fax: +420 541561111

[b] S. Skalickova, P. Horky, V. Mlejnkova, J. Skladanka Department of Animal Nutrition and Forage Production, Mendel University in Brno, Zemedelska 1, 61300 Brno, Czech Republic

[c] B. Hosnedlova, B.Ruttkay-Nedecky, R. Kizek

Department of Viticulture and Enology, Faculty of Horticulture, Mendel University in Brno, Valticka 337, CZ-691 44 Lednice, Czech Republic

[d] B.Ruttkay-Nedecký Department of Molecular Pharmacy, Faculty of Pharmacy, Masaryk University, Palackeho 1946/1, 61200 Brno, Czech Republic

[e] Carlos Fernandez

School of Pharmacy and Life Sciences, Robert Gordon University, Garthdee Road, AB10 7QB Aberdeen, UK

[f] R. Kizek

Department of Biomedical and Environmental Analyses, Faculty of Pharmacy, Wroclaw Medical University, Borowska 211, 50-556 Wroclaw, Poland wound healing, treatment of diabetes, target and personalised medicine. Over the past ten years, many breakthroughs in nanotechnology have occurred in medicine. The most important advances include cell reprogramming via skin nanochip ${ }^{1}$, antibacterial nanostructured surfaces ${ }^{2}$, tumor-targeting drugs ${ }^{3}$, single-cell nanosurgery ${ }^{4}$, nanofilms for wound dressings ${ }^{5}$ and many others. Biopolymeric nanoparticles (NPs) are commonly used in the field of medicine. This group includes compounds such as proteins, saccharides or fatty acids. Their popularity is supported by their natural origin, the possibility of large-scale production and non-toxicity. Particularly, polysaccharide nanoparticles (PNPs) are an intensively studied domain.

Over the past decade, the research trend is increasingly moving from particle design to clarifying interactions of PNPs in the organism. Forming the protein cluster around NPs has been intensively investigated in the past few years in connection with the elucidation of the fate of NPs in the body ${ }^{6}{ }^{7}$. It has been confirmed that PC defines biological identity and fate in the organism rather than pure nanoparticles ${ }^{8,9}$. It has been clear for several years that the PC opens new horizons for therapeutics. NPs create their unique fingerprint in the internal environment of organisms ${ }^{10}$. Understanding these phenomena at the molecular level will help to improve active targeting or diagnostics. This review focuses on exploring PNPs and the formation of the PC. Creating the PC opens up possibilities for theranostic use.

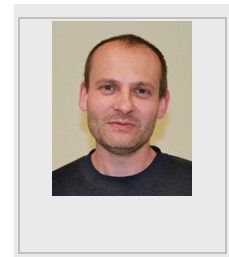

Professor Kizek is currently Professor at Pharmaceutical faculty (Masaryk University, Brno). Main research interests: A research interest is focused on heavy metals (like cadmium, lead and zinc) in the environment. Organisms produce a lot of protective molecules include the thiol compounds, in plants are phytochelatins, in animals are metallothioneins. Furthermore, these molecules may be used in bioremediation technology or biosensors. Moreover, he is focused on nanotechnology, synthesis of nanoparticles (chemical and/or biological), as magnetic, carbon or quantum dots. Their 
behavior in the environment is very important for plants and aquatic organisms. stabilisation, for example, with citrate, cysteine or other reducing agents ${ }^{38}$. Their functions can be more specific than just drug delivery. For example, they allow immune escape, carry specific functional groups on the surface or protect the nucleus from degradation in the body ${ }^{39}$. Many of them give metallic NPs biocompatibility, bioavailability, uptake and reduce toxicity.

\section{Interaction between polysaccharide-based nanoparticles and the PC}

Of the general nanoparticle design options, a significant percentage of them have incorporated polysaccharide molecules in their structure. Consequently, polysaccharides can play various roles in the main task of nanoparticles. Polysaccharide molecules could be self-assembled ${ }^{16,18}$ or crosslinked to form the nanotransporter with various cargo. In both methods, the strong electrostatic interactions exist between cargo and biopolymer cages as well as covalent bonds, and hydrogen bonding ${ }^{33}$. The most popular polymer is cationic CS, which readily forms NPs by crosslinking anionic agents such as glutaraldehyde or tripolyphosphate ${ }^{34}$.

By immersion in biofluid, a number of studies have reported the creation of PCs not only in metal NPs but also in PNPs as is demonstrated in Figure 1.

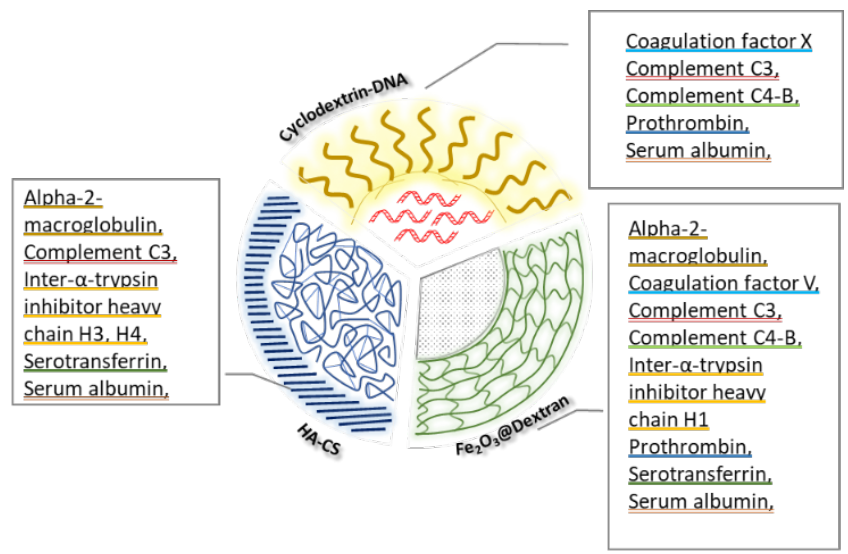

Figure 1: Three types of PNPs and occurrence of the PC. Cyclodextrin-DNA (transporter with cargo) ${ }^{40}$, HA-CS (PNPs) ${ }^{41}$ and $\mathrm{Fe}_{2} \mathrm{O}_{3}$-Dextran (core-shell NPs) ${ }^{42}$. The similar proteins are underlined with the same color. Other proteins represented in the $P C$ are listed in the Table 1.

$\mathrm{PC}$ is formed depending on the internal environment of the body which determines involved interactions with proteins and NPs ${ }^{43-}$ ${ }^{46}$. These interactions are commonly based on $\mathrm{H}$-bonds, van der Waals interactions, electrostatic interactions, hydrophobic interactions and $\pi-\pi$ stacking ${ }^{47}$. Strongly bonded proteins form a hard corona. Other proteins form a dynamic layer based on the Vroman effect - high-abundance, low-affinity proteins are dynamically replaced by lower-abundance higher-affinity proteins overtime during the nano-bio interaction ${ }^{48}$. Conformational changes of the adsorbed protein can result from surface curvature, topography and surface energy/hydrophobicity ${ }^{49}$. It has also been shown that PC composition varies depending on the environment ${ }^{43}, 44$. New studies on carbohydrate nanopolymers are beginning to routinely involve PC analysis using gel electrophoresis or mass 
spectrometry (MS) analysis. Table 1 gives an overview of the protein composition of the PC from available studies.

Tab. 1: Protein composition of the corona of polysaccharide NPs after $60 \mathrm{~min}$ at $37^{\circ} \mathrm{C}$. Detailed information can be found in the original articles.

\begin{tabular}{|c|c|c|c|c|c|}
\hline Nanoparticles & Medium & Method & Detected proteins & $\begin{array}{l}\text { Protein } \\
\text { size } \\
(\mathrm{KDa})\end{array}$ & $\begin{array}{l}\text { Ref } \\
\text { ere } \\
\text { nce } \\
\text { s }\end{array}$ \\
\hline $\begin{array}{l}\mathrm{Fe}_{3} \mathrm{O}_{4} @ \text { folic } \\
\text { acid- } \\
\text { chitosan } \\
\text { conjugate }\end{array}$ & $\begin{array}{l}\text { plasma } \\
\text { protein } \\
\mathrm{s}\end{array}$ & $\begin{array}{l}\text { SDS- } \\
\text { PAGE }\end{array}$ & $\begin{array}{l}\text { unspecified } \\
\text { proteins }\end{array}$ & $40-71$ & 50 \\
\hline $\begin{array}{l}\text { Chitosan- } \\
\text { folate } \\
\text { coated } \\
\text { mesoporous } \\
\text { silica NPs }\end{array}$ & $\begin{array}{l}\text { plasma } \\
\text { protein } \\
\mathrm{s}\end{array}$ & $\begin{array}{l}\text { SDS- } \\
\text { PAGE }\end{array}$ & $\begin{array}{l}\text { unspecified } \\
\text { proteins }\end{array}$ & $45-75$ & 51 \\
\hline $\begin{array}{l}\mathrm{Fe}_{2} \mathrm{O}_{3} @ \text { bet } \\
\text { a- } \\
\text { cyclodextrin } \\
\text {, loaded } \\
\text { doxorubicin- } \\
\text { curcumin }\end{array}$ & $\begin{array}{l}\text { human } \\
\text { blood } \\
\text { plasma }\end{array}$ & $\begin{array}{l}\text { SDS- } \\
\text { PAGE }\end{array}$ & $\begin{array}{l}\text { unspecified } \\
\text { proteins }\end{array}$ & $\begin{array}{l}25-35 \\
45-55\end{array}$ & 52 \\
\hline $\begin{array}{l}\mathrm{Fe}_{2} \mathrm{O}_{3} \\
\text { coated with } \\
\text { PEG- } \\
\text { chitosan }\end{array}$ & $\begin{array}{l}\text { human } \\
\text { blood } \\
\text { plasma }\end{array}$ & $\begin{array}{l}\text { SDS- } \\
\text { PAGE }\end{array}$ & $\begin{array}{l}\text { Apolipoprotein } \\
\text { Transferin } \\
\text { Vitronectin }\end{array}$ & $\begin{array}{l}28 \\
80 \\
75\end{array}$ & 53 \\
\hline $\begin{array}{l}\text { Chitosan } \\
\text { NPs }\end{array}$ & $\begin{array}{l}\text { fetal } \\
\text { bovine } \\
\text { serum }\end{array}$ & $\begin{array}{l}\text { LC-MS, } \\
\text { SDS- } \\
\text { PAGE }\end{array}$ & $\begin{array}{l}\text { Alpha- } \\
\text { fetoprotein } \\
\text { Alpha-1- } \\
\text { antiproteinase } \\
\text { Alpha-1B- } \\
\text { glycoprotein } \\
\text { Alpha-2-HS } \\
\text { glycoprotein } \\
\text { Alpha-2- } \\
\text { macroglobulin } \\
\text { Complement C3 } \\
\text { Clusterin } \\
\text { Galectin-3- } \\
\text { binding protein } \\
\text { Hemoglobin fetal } \\
\text { subunit beta } \\
\text { Inter-alpha- } \\
\text { trypsin Inhibitor } \\
\text { heavy chain H3 } \\
\text { ITIH2 protein } \\
\text { Keratin, type II } \\
\text { cytoskeletal } 7 \\
\text { Serotransferrin } \\
\text { Serpin A3-2 } \\
\text { Serum albumin }\end{array}$ & $\begin{array}{l}\text { not } \\
\text { given }\end{array}$ & \\
\hline $\begin{array}{l}\text { Hyaluronic } \\
\text { acid-coated } \\
\text { chitosan } \\
\text { NPs }\end{array}$ & $\begin{array}{l}\text { fetal } \\
\text { bovine } \\
\text { serum }\end{array}$ & $\begin{array}{l}\text { LC-MS, } \\
\text { SDS- } \\
\text { PAGE }\end{array}$ & $\begin{array}{l}\text { Alpha- } \\
\text { fetoprotein } \\
\text { Alpha-1-acid } \\
\text { glycoprotein } \\
\text { Alpha-1- } \\
\text { antiprotease } \\
\text { Alpha-1B- } \\
\text { glycoprotein } \\
\text { Alpha-2-HS } \\
\text { glycoprotein } \\
\text { Alpha-2- } \\
\text { macroglobulin } \\
\text { Complement C3 } \\
\text { Inter-alpha- } \\
\text { trypsin inhibitor } \\
\text { heavy chain H3 } \\
\text { Inter-alpha- } \\
\text { trypsin inhibitor } \\
\text { heavy chain H4 } \\
\text { Keratin, type II } \\
\text { cytoskeletal } 7 \\
\text { Serotransferrin } \\
\text { Serpin A3-2 } \\
\text { Serum albumin }\end{array}$ & $\begin{array}{l}\text { not } \\
\text { given }\end{array}$ & 41 \\
\hline $\begin{array}{l}\text { Alginate- } \\
\text { coated } \\
\text { chitosan } \\
\text { NPs }\end{array}$ & $\begin{array}{l}\text { fetal } \\
\text { bovine } \\
\text { serum }\end{array}$ & $\begin{array}{l}\text { LC-MS, } \\
\text { SDS- } \\
\text { PAGE }\end{array}$ & $\begin{array}{l}\text { ALB protein } \\
\text { Alpha-1- } \\
\text { antiproteinase } \\
\text { Alpha-2-HS } \\
\text { glycoprotein }\end{array}$ & $\begin{array}{l}\text { not } \\
\text { given }\end{array}$ & \\
\hline
\end{tabular}

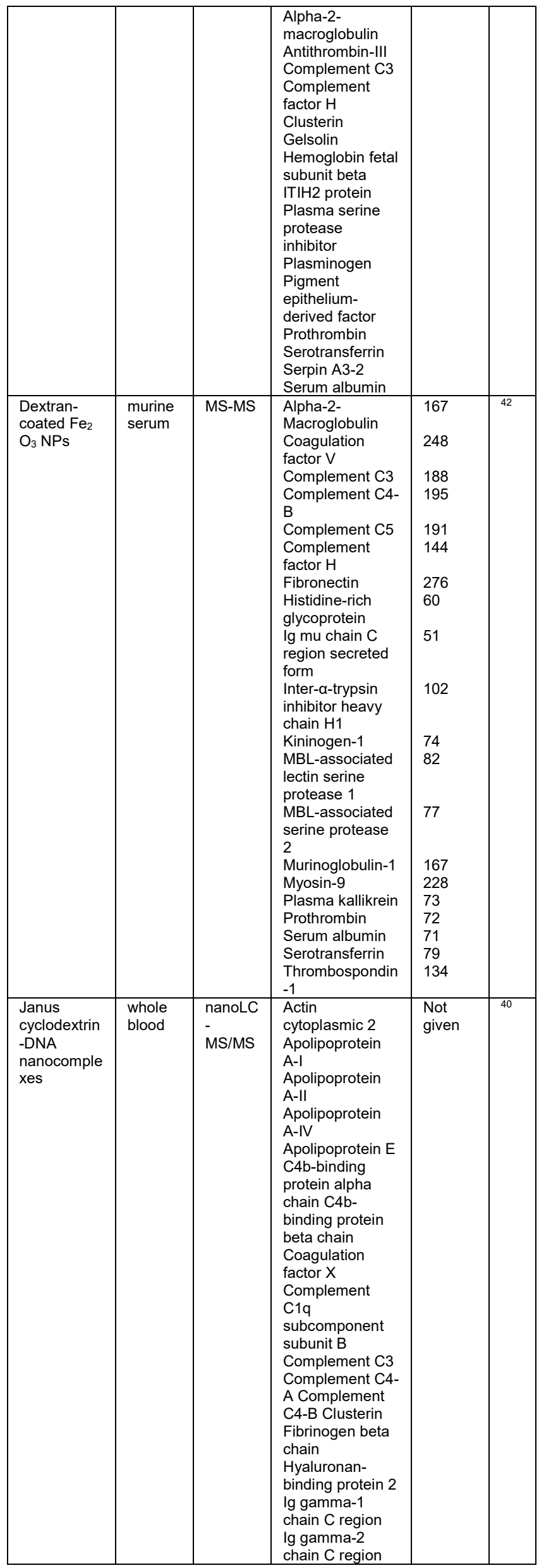




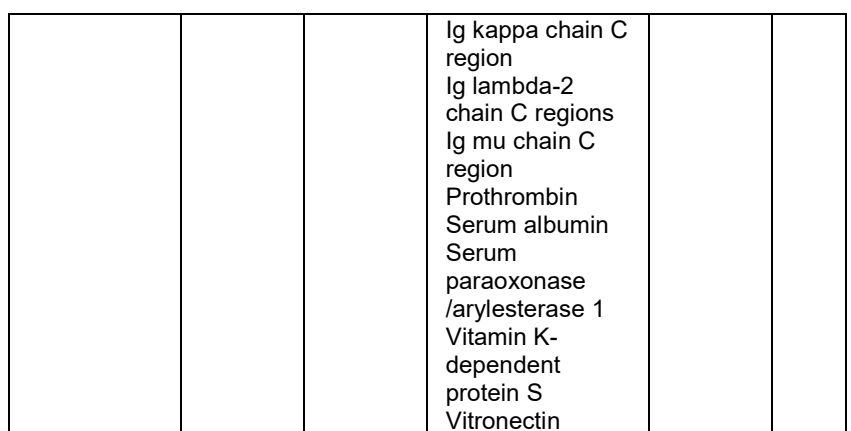

In the biological systems the interaction between proteins and polysaccharides are weak or in the case of oppositely charged molecules, there are weak electrostatic interactions ${ }^{54}$. According to Flory-Huggins theory proteins and polysaccharides can form single-phase mixed solutions only if their interaction is exothermic Thermodynamic incompatibility generally occurs under conditions where the protein is in the presence of a neutral polysaccharide or an anionic polysaccharide bearing the charge of the same sign as the protein. When the total polymer concentration change, the phases may be homogeneous or heterogeneous. In the case of high concentrations of proteins and polysaccharides, coacervates are formed. The interaction also depends on the biopolymer structure. Some proteins have amino acid regions, known as binding pockets, that are able to bind polysaccharides, either through hydrogen bonding or $\pi-\pi$ stacking. Some linear polysaccharides may have a molecular backbone for crosslinking and protein binding or the proteins may bind to deep grooves of polysaccharide subunits ${ }^{55}$.

A group of highly specific proteins for binding affinity to polysaccharides are lectins. Lectins are a wide protein familly which perform important functions in the organisms; e.g. regulate cell adhesion, control protein levels in the blood, bind glycoproteins, interfere with the immune system response. Lectins are classified as either exo- or endo-types. Exo-type lectins interact with terminal units of polysaccharides and bind glycan chains in partially sealed clefts. Lectins of this type specifically bind to the terminal cap structure. In contrast, endotype lectins interact with internal units of polysaccharides using open clefts. Endo-type lectins enhance binding affinity to polysaccharide ligands by three mechanisms: (1) Multiple-site interactions; (2) Repeated binding; (3) Recognition of ordered/higher-ordered polysaccharide structure ${ }^{56}$. The binding properties of lectins are affected by the shape of the binding sites in polysaccharides or the branching of the polysaccharide, changes in molecular conformations. The lectin interactions have been described for important polysaccharides used in the nanoparticle design: chitosan, dextran, hyaluronic acid, cellulose, alginate, pectin, xanthan and guar gum as well as many others. Particularly, PNPs such as dextran, HA, as well as CS, bind fewer proteins than, for example, inorganic NPs ${ }^{41}$. Existing results showed the influence of PC on the functionality of CS NPS. Varnamkhasti et al. used CS NPs conjugated by HA and decorated by mucin 1 aptamer as a carrier for camptothecin. It was shown that aptamer decoration increased the uptake of NPs by specific cell lines. However, after the PC formation, CS/HANPs lost their targeting abilities. The study also confirmed, that there was no difference between the cytotoxicity of targeted and non-targeted NPs when treated with bovine serum albumin prior to cytotoxicity study ${ }^{57}$. Also, another study showed that PC could affect CS NPs degradation rate, which was demonstrated by a reduction of availability of CS NPs for pancreatic enzymes in a dose-dependent manner ${ }^{58}$. In some cases, the formation of a protein corona may not prevent the functionality of the prepared nanoparticles. CS-NPs modified with the amino acids lysine and glutamic acid were designed to chelate copper ions and prevent cytotoxicity and ROS production of $\mathrm{CuO} \mathrm{NPs}^{59}$. Despite the PC formed, which predominantly contained albumin, the chelating efficiency was not significantly reduced ${ }^{3}$. However, PC may not be created at all. This phenomenon has been mainly observed in the case of polymeric NPs ${ }^{60}$.

While polymers such as polyethylene glycol (PEG) are widely used for stealth strategy, dextran may have the opposite effects 61. Dextran (3.5-5 kDa) was introduced on the surface sperminefunctionalized NPs. Results showed the higher NPs uptake by macrophages and dendritic cells. Binding of dextranylated particles to antigen-presenting cells results in an upregulation of surface maturation markers and elevated production of proinflammatory cytokines. Dextranylated particles can potentially be used for passive targeting of antigen-presenting cells with inherent adjuvant function for future immunotherapeutic applications ${ }^{62}$.

\section{The perspective of the PC in theranostics}

NPs excel in targetability and multifunctionality for theranostic purposes as well as properties allowing the effect of the increased permeability and crossing the blood-brain barrier (BBB). Several types of NPs have been designed to enable treatment and response monitoring. PNPs have some advantages over other nanoparticles (e.g., metallic or carbon) such as biocompatibility, biodegradability, and bioadhesion properties. The PC is formed in PNPs by a different mechanism, in which its formation can be reduced ${ }^{63}$. These qualities should be specifically included in therapeutic treatments. We designed a scheme of the PC potential in theranostics (Fig. 2). Three primary strategies are evident: I) utilization of the PC in therapy; II) composition of the PC is analysed for specific disease markers; III) how the formed PC can interact with the immune system and enhance the immunomodulation or immunoelimination. However, these three states may exist separately or together. The following sections summarise the new findings on these objectives.

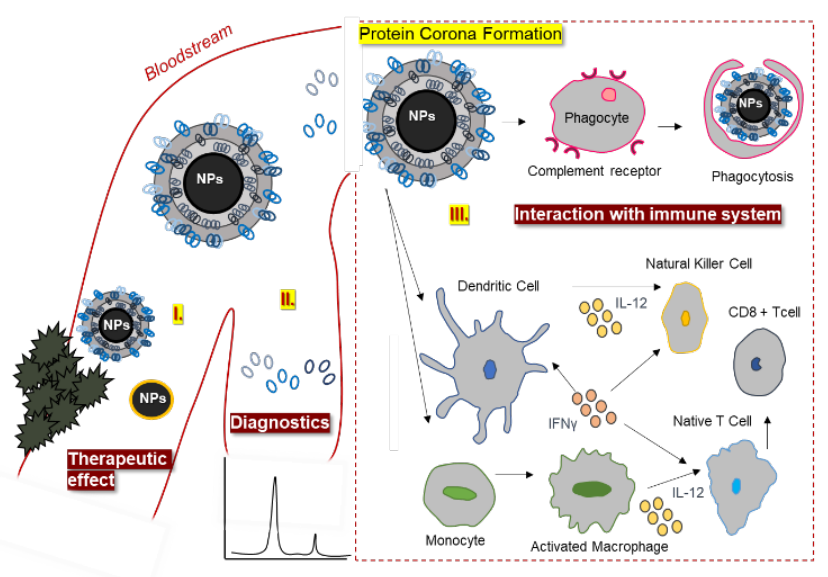

Figure 2. Three strategies of the NPs' corona potential in theranostics. I) NPs retain their therapeutic effect with or without PC. II) NPs corona composition could be used as a specific marker in diagnostics. III) NPs corona has an impact on the immune system. PC contains complement components that help immune 
cells to recognise NPs. PC could interact with phagocytes which leads to phagocytosis. The recognition by dendritic cells or monocytes leads to the production of cytokines [e.g., interleukin 12 (IL-12) or interferon gamma (IFNY)] and excitement of natural killer cells, macrophages or T cells.

\subsection{Therapeutic effect of the PC}

Polysaccharide NPs have already shown potential in many therapeutic applications ${ }^{64}$. Some of them have already undergone clinical trials. Although the passive delivery predominates in the application, there are still new designs using active targeting elements ${ }^{65}$. However, several active drug delivery projects failed due to the PC formation and unpredicted nano-bio interactions. Taking into account the fact that the PC is formed anyway, it offers a therapeutic direction in two ways:

i) a restriction of the $P C$ formation to maintain the original functionality of NPs. In this case, coating by polymers (PEG, polyoxyethylene, poloxamine, zwitterions ${ }^{66}$ or polysaccharides such as CS ${ }^{67,68}$ ) could be employed. CS is an important natural proton sponge material that facilitates endosomal escape. The negative surface polymeric micelles consisted of polymethyacrylamide linked to the CS by $3,3^{\prime}$-dithiodipropionic acid could resist the adsorption of serum proteins and maintain its nature and monodispersity ${ }^{69}$. CS coating could also protect the functionality of the RGD (Arg-Gly-Asp) peptide decoration of silica NPs ${ }^{70}$. The combination of CS and PEG as a coating for doxorubicin-loaded magnetic NPs was applied to MCF7 breast cancer cell lines. SEM photography comparison showed no observed changes in the NPs size after in vitro incubation in human blood plasma. However, the SDS-PAGE analysis confirmed the PC formation in the nanocarrier-corona complex ${ }^{53}$. Instead of the CS, other polysaccharides are suitable for NPS modification to control the stealth strategy. Subramaniyan et al. designed a jacalin-functionalized pectin-capped copper sulfide NPs to maintain the antibacterial activity. The higher interaction with albumin was observed in the unfunctionalized PNPs as expected. Moreover, the jackalin is supposed to mediate the interaction through bacterial cell surface glycan recognition. However, the main weakness of this study was the failure to test the nanocomposite in biological fluid. Although in vivo results on zebrafish showed higher antibacterial efficacy with jackalinfunctionalized PNPs ${ }^{71}$. A similar mechanism has been applied to targeting dendritic cells. Hydroxyethyl starch nanocarriers were PEGylated and functionalized at the outerlayer with mannose. The PC was significantly reduced compared to unPEGylated nanocarrier as well as the protein composition differed. PNPs have shown the presence clusterin (apolipoprotein I) which is associated with stealth $\mathrm{PC}^{72}$. Similar results have been observed in the hydroxyethyl starch, dextran and glucose functionalized nanocarriers ${ }^{73}$

ii) NPs design to enhance the creation of a specific PC. This effect could include specific interaction between lectins and polysaccharides ${ }^{74}$. Lectins are related to various biological diseases, including viral infection and cancer metastasis. In particular, galactose-binding lectins have NPs used as a target for drug delivery and cancer markers. Tsutsumi et al. designed gold nanoparticles conjugated with glycopeptides and successfully used this system for galactose binding lectin RCA120 detection and imaging on the cell surface ${ }^{75,76}$. Another study has proven the dextran-coated ferrous NPs activate the lectin complement pathway in vitro and in vivo. The formed lectin PC activated complement factor 3 resulting in B-cell effective targeting leading to the treatment of systemic anaphylaxis and allergic asthma in mouse models ${ }^{42}$. The formation of the PC could be useful for nanovaccine design which mimics host pathogens by presenting lectins on their surface.

The beneficial effect of the interaction between PNPs and PC has been shown as a powerful and potential strategy to overcome neurodegenerative disorders. PC consisted of apolipoproteins could overcome the blood-brain barrier. At the experimental level, PNPs were found to be able to promote or inhibit the aggregation of amyloid proteins, which are responsible for one of the main mechanisms of neurodegeneration ${ }^{77}$. The hypothesis confirmed the ability of chitosan-amyloid- $\beta$ PNPs to overcome BBB and bind on exposed hydrophobic patches of aggregated proteins what might lead to their correct folding. In these cases, PNPs and other NPs could act as artificial chaperones ${ }^{78}$. In this way, NPs offer the use of peptide motifs to recruit specific protein with requested properties. In this domain, the CS NPs are one of the most promising. Another study showed the PC outlook in gene delivery, where cyclodextrin with self-assembled properties and biomimetic cell-membrane-crossing aptitudes served as molecular gene vectors. In the presence of nucleic acids, they spontaneously form well-defined supramolecular nanocomplexes where the gene material is protected from degradation by enzymatic agents. Changes of PC composition showed the cationic charge of bound proteins caused by electrostatic interactions between NPs and proteins. Regarding the function of nanovector, it is evident that the DNA transfection was affected by $\mathrm{PC}{ }^{40}$.

\subsection{Role of the $P C$ in diagnostics}

More recent attention has been focused on the potential of the PC in becoming a personalised diagnostic tool ${ }^{79}$. A growing body of literature has investigated PC fingerprinting in body fluids ${ }^{80}$. The exceptional role of $\mathrm{PC}$ lies in the dynamics of its production and very sensitive changes in composition ${ }^{79}$, which are conditioned by health ${ }^{81}$, satiety ${ }^{82}$ or performance of the immune system ${ }^{83}$. A recent study used a formed $P C$ in a proteomic study for cancer biomarkers screening ${ }^{84}$. Therefore, there has been an increase in the interest of using the PC as a diagnostic tool. Unlike metal NPs, which are also being further explored in this regard, the discovery of PNPs is just the beginning.

One of the first serious discussions and analyses of the diagnostic potential of PC have been proved on the animal model. The experimental work was focused on mastitis detection using magnetic NPs. The proteomic study and protein fingerprinting proved the presence of $\alpha_{\mathrm{s} 2}$-casein and lactoferrin in samples from cows with mastitis ${ }^{85}$. Thus, both proteins are associated with the control of internal infectious mechanisms ${ }^{86}$

The disadvantage of PC diagnostics is a complex proteomic analysis that requires at least gel electrophoresis, but preferably MS. It may be limiting for many diagnostic medical centers. On the contrary, magnetic resonance imaging (MRI) is a standard procedure around the world. Iron oxide superparamagnetic NPs coated by phosphatidylcholine could be employed as a contrast agent for atherosclerotic plaque detection. Thus, NPs design caused the specific composition of PC, which mainly consists of ApoB lipoproteins mimicking low-density lipoprotein (LDL). Specific nanomarkers then accumulate in plaque and could be detected by using MRI ${ }^{87}$. It could be expected that similar applications will also occur with polysaccharide, as some research studies suggest ${ }^{88}$. Maghemite nanoparticles coated with dextran were prepared to obtain water-dispersible 
nanoparticles. To ensure their internalization process by the cells, they were further coated with chitosan ${ }^{89}$.

\subsection{Protein corona stimulates or mitigates the immune response}

The immune system is dynamically connected with nervous and hormonal systems which influence each other and together form the immune response. The immune response is a mechanism of molecular interactions, which is triggered by foreign invaders NPs. Generally, NPs are immediately recognized by complement leading to opsonisation and PC formation ${ }^{90}$. This mechanism is associated with the mononuclear phagocytic system ${ }^{91}$. Moreover, some studies have proven that the NPs could be recognised by $B$ or T lymphocytes, which belong to the adaptive immunity ${ }^{17,92}$. A number of studies have sought to find a link between NPs character and their fate in the body. The latest findings agree that the more hydrophobic, negative-charged NPs, the more rapid interaction with blood proteins occur 93, 94. For example, zwitterionic ligands such as amino acids or glycine are likely captured by dendritic cells than PEGylated surfaces ${ }^{95}$. Whereas hydrophilic, neutral NPs are more tolerated, surface hydrophilicity conduces for suppressing plasma proteins interactions ${ }^{93}$. The low electrokinetic potential of negatively charged NPs could induce phagocytosis ${ }^{96}$. Equally important is the shape of the NPs. Several studies have proven that the spherical shape was more accessible to components of the immune system ${ }^{95}$ and bigger particles are more rapidly internalised by macrophages via a mannose receptor-mediated pathway ${ }^{97,98}$.

PNPs are often used in the belief that they can use stealth strategies to bypass immune system responses. In the NPs design approaches, there are usually used coating techniques to avoid the immune response. The most abundant polymers are PEG, dextran, and CS 99,100 . Sarmento et al. demonstrated that the insulin-loaded solid lipid NPs have been strongly internalized by macrophages in comparison with CS-coated NPs ${ }^{101}$. The findings of the study led to the fact that CS nanodevices can prolong the circulation time of the cargo and avoid phagocytosis after intestinal uptake. However, the research did not take into account internal conditions, which led to the PC formation and opsonisation and also the interaction with other parts of the immune system. It has to be mentioned, that the kinetics of NPs interactions determines binding properties to the cell surface. In another study, alginate-CS core-shell vehicle impact on human peripheral blood mononuclear cells in vitro has been investigated. Toma et al. found that T cells, B cells and NK cells (nonphagocytic cells) were preferentially internalised by monocytes via negatively charged sialic acid on their surface ${ }^{102}$. Moreover, flow cytometry and MTT (3-[4,5-dimetylthiazol-2-yl]-2,5-diphenyltetrazolium bromide) test confirmed a good viability of macrophages and nonoverall toxicity on human peripheral blood mononuclear cells. The findings of the study suggested that CS-alginate core-shell vehicles are more attractive for translation into preclinical investigations.

The second option is to use PNPs as adjuvants that are able to stimulate an immune response. Chitosan PNPs has been the most explored for this possibility ${ }^{103}$. Previous studies reported that CS could enhance both humoral and cell-mediated immune responses after subcutaneous vaccination ${ }^{104-107}$. In the research by Zaharoff et al. was found that CS is better than Freund adjuvant or aluminium hydroxide adjuvant in enhanced antigenspecific antibody titers and splenic CD4+ proliferation ${ }^{108}$. It has been estimated several advantages of CS, e.g., the high surface area and positive surface charge leads to the adsorption increase of the proteins that form PC ${ }^{109}$. Moreover, it has been reported that CS PNPs are able to pass through tight junctions ${ }^{106}$. Chuang et al. demonstrated that fucoidan-quaternary CS PNPs for anthrax vaccine exhibited no cytotoxicity and immunotoxicity toward dendritic cells as well as excellent uptake efficacy. Instead of CS, some other polysaccharides were found suitable for adjuvants. Yakubogullari et al. introduced Astragaloside VII polysaccharide based adjuvant for influenza A vaccine 110 . Furthermore, alginate PNPs ${ }^{111}$, hyaluronidase combined with dextran ${ }^{112}$, cellulose nanomaterials ${ }^{113}$, inulin PNPs ${ }^{114}$, cholesteryl pullulan PNPs ${ }^{115}$ were confirmed as potential vaccine adjuvants.

\section{Conclusion and future perspectives}

The PC determines the fate of PNPs and their use in theranostics. On the one hand, efforts are being made to eliminate PC formation; on the other hand, scientists accept this challenge and take advantage of the nano-bio interactions. Although these effects are known, the context with NPs composition is not yet well understood. Therefore, the information about interactions on the PNPs biological interface is necessary for deepening knowledge in the field of diagnostics. It could be assumed that the $\mathrm{PC}$ will be rapidly employed to sensor and biosensor construction. As mentioned in this review, the unique PC fingerprint could correlate with a specific disease. This outlook also defines the way for a possible theranostic direction and developing of noninvasive diagnostic methods. Taking into account current analytical capabilities, improved techniques will bring more opportunities to enhancing quality observation, the interface between nanotechnology and biology. In conclusion, PC aspires to be an interesting and perspective tool in the theranostics.

\section{Acknowledgements}

This work was supported by the LPR_273/2019, NANOCSDOXO 306/2018/FaF and CA LTC18002. CF would like to express his gratiude to PALS for support.

Conflicts of Interest: The authors declare that they have no conflict of interest.

Key words: chitosan; stealth strategy, drug delivery; immune response; diagnostics 
Three strategies of the NPs' corona potential in theranostics. I) NPs retain their therapeutic effect with or without PC. II) NPs corona composition could be used as a specific marker in diagnostics. III) NPs corona has an impact on the immune system. PC contains complement components that help immune cells to recognise NPs. PC could interact with phagocytes which leads to phagocytosis. The recognition by dendritic cells or monocytes leads to the production of cytokines [e.g., interleukin 12 (IL-12) or interferon gamma (IFNy)] and excitement natural killer cells, macrophages or T cells

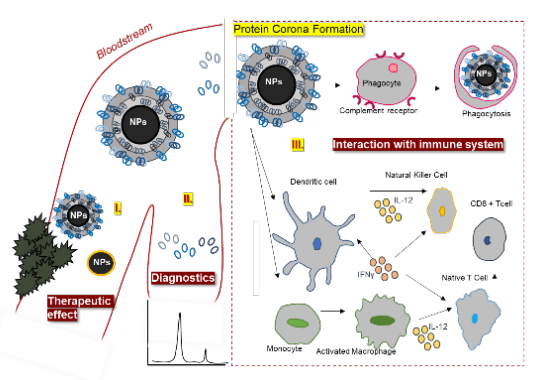

Sylvie Skalickova ${ }^{a, b}$, Pavel Horky ${ }^{b}$, Veronika Mlejnkova ${ }^{b}$, Jiri Skladanka ${ }^{b}$ Bozena Hosnedlovac, Branislav RuttkayNedecky ${ }^{c, d}$, Carlos Fernandez ${ }^{e}$ Rene Kizek $^{a, c, f^{*}}$

Theranostic Approach for the Protein Corona of Polysaccharide Nanoparticles

1 M. W. Lensch, C. L. Mummery, Stem Cell Reports 2013, 1, 5-17 10.1016/j.stemcr.2013.05.001.

2 Y. Yuan, Y. Zhang, Nanomedicine-Nanotechnology Biology and Medicine 2017, 13, 2199-2207

10.1016/j.nano.2017.06.003.

3 Y. Y. Li, C. H. Jiang, D. W. Zhang, Y. Wang, X. Y. Ren, K. L. Ai, X. S. Chen, L. H. Lu, Acta Biomaterialia 2017, 47, 124-134 10.1016/j.actbio.2016.10.010.

4 G. D. M. Jeffries, J. S. Edgar, Y. Q. Zhao, J. P. Shelby, C. Fong, D. T. Chiu, Nano Letters 2007, 7, 415-420 $10.1021 / \mathrm{n} 10626784$.

5 B. Sibaja, E. Culbertson, P. Marshall, R. Boy, R. M. Broughton, A. A. Solano, M. Esquivel, J. Parker, L. De la Fuente, M. L. Auad, Carbohydrate Polymers 2015, 134, 598-608 10.1016/j.carbpol.2015.07.076.

6 G. Caracciolo, O. C. Farokhzad, M. Mahmoudi, Trends in Biotechnology 2017, 35, 257-264 10.1016/j.tibtech.2016.08.011.

7 N. Van Hong, B.-J. Lee, International Journal of Nanomedicine 2017, 12, 3137-3151 10.2147/ijn.s129300.

8 I. Lynch, K. A. Dawson, Nano Today 2008, 3, 40-47 10.1016/s1748-0132(08)70014-8.

9 M. Mahmoudi, I. Lynch, M. R. Ejtehadi, M. P. Monopoli, F. B. Bombelli, S. Laurent, Chemical Reviews 2011, 111, 5610-5637 10.1021/cr100440g.

10 C. D. Walkey, J. B. Olsen, F. Song, R. Liu, H. Guo, D. W. H. Olsen, Y. Cohen, A. Emili, W. C. W. Chan, Acs Nano 2014, 8, 2439-2455 10.1021/nn406018q.

11 F. Seidi, R. Jenjob, T. Phakkeeree, D. Crespy, Journal of Controlled Release 2018, 284, 188-212 10.1016/j.jconrel.2018.06.026.

12 J. Zhu, X. Guo, T. Guo, Y. Yang, X. Cui, J. Pan, Y. Qu, C. Wang, Rsc Advances 2018, 8, 40308-40320 $10.1039 / \mathrm{c} 8 \mathrm{ra} 07202 \mathrm{~g}$.

13 H. Dou, M. Tang, W. Yang, K. Sun, Colloid and Polymer Science 2007, 285, 1043-1047 10.1007/s00396007-1657-1.

14 P. S. Pramod, N. U. Deshpande, M. Jayakannan, Journal of Physical Chemistry B 2015, 119, 10511-10523 10.1021/acs.jpcb.5b05795.

15 D. Zeng, J. Zhao, K.-H. Luk, S.-T. Cheung, K.-H. Wong, T. Chen, Journal of Agricultural and Food Chemistry 2019, 67, 2865-2876 10.1021/acs.jafc.9b00193.

16 B. B. Breitenbach, I. Schmid, P. R. Wich, Biomacromolecules 2017, 18, 2839-2848

10.1021/acs.biomac.7b00771.

17 S. Singha, K. Shao, K. K. Ellestad, Y. Yang, P. Santamaria, Acs Nano 2018, 12, 10621-10635

10.1021/acsnano.8b05950.

18 X. Yang, X. Shi, R. D'Arcy, N. Tirelli, G. Zhai, Journal of Controlled Release 2018, 272, 114-144

10.1016/j.jconrel.2017.12.033. 
19 A. C. Mendes, T. Strohmenger, F. Goycoolea, I. S. Chronakis, Colloids and Surfaces a-Physicochemical and Engineering Aspects 2017, 531, 182-188 10.1016/j.colsurfa.2017.07.044.

20 S. Pistone, D. Qoragllu, G. Smistad, M. Hiorth, Colloids and Surfaces B-Biointerfaces 2016, 146, 136-143 10.1016/j.colsurfb.2016.05.055.

21 D. M. Cabezas, G. N. Pascual, J. R. Wagner, G. G. Palazolo, Food Hydrocolloids 2019, 95, 445-453

10.1016/j.foodhyd.2019.04.040.

22 X. F. Hou, Y. Chen, Y. Liu, Soft Matter 2015, 11, 2488-2493 10.1039/c4sm02896a.

23 D. Y. Ren, J. R. Qi, A. Q. Xie, M. F. Jia, X. B. Yang, H. Xiao, Journal of Functional Foods 2017, 38, $100-$

109 10.1016/j.jff.2017.09.004.

24 A. W. Simonson, A. Lawanprasert, T. D. P. Goralski, K. C. Keiler, S. H. Medina, Nanomedicine-

Nanotechnology Biology and Medicine 2019, 17, 391-400 10.1016/j.nano.2018.10.008.

25 P. S. Pramod, R. Shah, S. Chaphekar, N. Balasubramanian, M. Jayakannan, Nanoscale 2014, 6, $11841-$

$1185510.1039 / \mathrm{c} 4 \mathrm{nr} 03514 \mathrm{c}$.

26 H. Wang, T. T. Dai, S. L. Li, S. Y. Zhou, X. J. Yuan, J. Y. You, C. L. Wang, V. Mukwaya, G. D. Zhou, G. J. Liu, X. H. Wei, H. J. Dou, Acta Biomaterialia 2018, 72, 206-216 10.1016/j.actbio.2018.03.024.

27 H. Xiong, J. Ni, Z. J. Jiang, F. C. Tian, J. P. Zhou, J. Yao, Biomaterials Science 2018, 6, 2527-2540 $10.1039 / \mathrm{c} 8 \mathrm{bm} 00570 \mathrm{~b}$.

28 Y. L. Luo, X. J. Yin, X. Yin, A. Q. Chen, L. L. Zhao, G. Zhang, W. B. Liao, X. X. Huang, J. Li, C. Y. Zhang, Pharmaceutics 2019, 11, 176

10.3390/pharmaceutics11040176.

29 H. Zhang, S. Cui, H. Lv, X. Pei, M. Gao, S. Chen, J. Hu, Y. Zhou, Y. Liu, Carbohydrate Polymers 2019, 215, 130-136 10.1016/j.carbpol.2019.03.075.

30 Y. Zhang, Z. Cui, H. Mei, J. Y. Xu, T. Zhou, F. Cheng, K. P. Wang, Carbohydrate Polymers 2019, 219 , 143-154 10.1016/j.carbpol.2019.04.041.

31 M. L. Zhou, J. R. Hou, Z. R. Zhong, N. Hao, Y. Lin, C. H. Li, Drug Delivery 2018, 25, 716-722

10.1080/10717544.2018.1447050.

32 M. Zhou, K. Khen, T. Wang, Q. Hu, J. Xue, Y. Luo, Food Chemistry 2018, 239, 840-847

10.1016/j.foodchem.2017.07.019.

33 H. Maeda, H. Kobayashi, T. Miyahara, Y. Hashimoto, K. Akiyoshi, S. Kasugai, Journal of Biomedical

Materials Research Part B-Applied Biomaterials 2017, 105, 544-550 10.1002/jbm.b.33571.

34 X. Sun, P. Jia, T. Zhe, T. Bu, Y. Liu, Q. Wang, L. Wang, Food Hydrocolloids 2019, 96, 402-411

10.1016/j.foodhyd.2019.05.040.

35 A. Bibi, S.-u. Rehman, A. Yaseen, Materials Research Express 2019, 6, 092001

10.1088/2053-1591/ab2016.

36 S. Y. Lee, S. H. Ko, J. S. Shim, D. D. Kim, H. J. Cho, Acs Applied Materials \& Interfaces 2018, 10, 36628$3664010.1021 /$ acsami.8b08243.

37 Y. Wu, X. Zhang, H. Li, P. Deng, H. Li, T. He, J. Rong, J. Zhao, Z. Liu, Journal of Materials Chemistry B 2018, 6, 6646-6659 10.1039/c8tb00633d.

38 J. Szafraniec, J. Odrobinska, D. Lachowicz, G. Kania, S. Zapotoczny, Polimery 2017, 62, 509-515

10.14314/polimery.2017.509.

39 B. Kang, P. Okwieka, S. Schoettler, O. Seifert, R. E. Kontermann, K. Pfizenmaier, A. Musyanovych, R.

Meyer, M. Diken, U. Sahin, V. Mailaender, F. R. Wurm, K. Landfester, Biomaterials 2015, 49, 125-134

10.1016/j.biomaterials.2015.01.042.

40 M. Martinez-Negro, G. Caracciolo, S. Palchetti, D. Pozzi, A. L. Capriotti, C. Cavaliere, A. Lagana, C. Ortiz Mellet, J. M. Benito, J. M. Garcia Fernandez, E. Aicart, E. Junquera, Biochim Biophys Acta Gen Subj 2017, 7, 16. 41 A. Almalik, H. Benabdelkamel, A. Masood, I. O. Alanazi, I. Alradwan, M. A. Majrashi, A. A. Alfadda, W. M. Alghamdi, H. Alrabiah, N. Tirelli, A. H. Alhasan, Scientific Reports 2017, 7, 10542

10.1038/s41598-017-10836-7.

42 L. Shen, S. Tenzer, W. Storck, D. Hobernik, V. K. Raker, K. Fischer, S. Decker, A. Dzionek, S.

Krauthauser, M. Diken, A. Nikolaev, J. Maxeiner, P. Schuster, C. Kappel, A. Verschoor, H. Schild, S. Grabbe, M. Bros, J Allergy Clin Immunol 2018, 142, 1558-1570.

43 M. R. Findlay, D. N. Freitas, M. Mobed-Miremadi, K. E. Wheeler, Environmental Science-Nano 2018, 5, 64-71 10.1039/c7en00466d.

44 A. Cox, P. Andreozzi, R. Dal Magro, F. Fiordaliso, A. Corbelli, L. Talamini, C. Chinello, F. Raimondo, F. Magni, M. Tringali, S. Krol, P. J. Silva, F. Stellacci, M. Masserini, F. Re, Acs Nano 2018, 12, 7292-7300 10.1021/acsnano.8b03500. 
45 F. Charbgoo, M. Nejabat, K. Abnous, F. Soltani, S. M. Taghdisi, M. Alibolandi, W. T. Shier, T. W. J. Steele, M. Ramezani, Journal of Controlled Release 2018, 272, 39-53 10.1016/j.jconrel.2018.01.002.

46 L. M. Shen, S. Tenzer, W. Storck, D. Hobernik, V. K. Raker, K. Fischer, S. Decker, A. Dzionek, S.

Krauthauser, M. Diken, A. Nikolaev, J. Maxeiner, P. Schuster, C. Kappel, A. Verschoor, H. Schild, S. Grabbe, M. Bros, Journal of Allergy and Clinical Immunology 2018, 142, 1558-1570 10.1016/j.jaci.2017.08.049.

47 P. C. Ke, S. Lin, W. J. Parak, T. P. Davis, F. Caruso, Acs Nano 2017, 11, 11773-11776

10.1021/acsnano.7b08008.

48 S. M. Ahsan, C. M. Rao, M. F. Ahmad, in Cellular and Molecular Toxicology of Nanoparticles, ed. by Q.

Saquib, M. Faisal, A. A. AlKhedhairy, A. A. Alatar, 2018, Vol. 1048, pp. 175-198.

49 S. Galmarini, U. Hanusch, M. Giraud, N. Cayla, D. Chiappe, N. von Moos, H. Hofmann, L. Maurizi, Bioconjugate Chemistry 2018, 29, 3385-3393 10.1021/acs.bioconjchem.8b00554.

50 V. Nejadshafiee, H. Naeimi, B. Goliaei, B. Bigdeli, A. Sadighi, S. Dehghani, A. Lotfabadi, M. Hosseini, M. S. Nezamtaheri, M. Amanlou, M. Sharifzadeh, M. Khoobi, Materials Science and Engineering: C 2019, 99, 805815 https://doi.org/10.1016/j.msec.2019.02.017.

51 M. P. Daryasari, M. R. Akhgar, F. Mamashli, B. Bigdeli, M. Khoobi, Rsc Advances 2016, 6, 105578-105588 $10.1039 / \mathrm{c} 6 \mathrm{ra} 23182 \mathrm{a}$.

52 R. Rastegar, H. A. Javar, M. Khoobi, P. D. Kelishadi, G. H. Yousefi, M. Doosti, M. H. Ghahremani, A. Shariftabrizi, F. Imanparast, E. Gholibeglu, M. Gholami, Artificial Cells Nanomedicine and Biotechnology 2018, 46, 207-216 10.1080/21691401.2018.1453829.

53 M. Rahimi, V. Shafiei-Irannejad, K. D. Safa, R. Salehi, Carbohydrate Polymers 2018, 196, 299-312 https://doi.org/10.1016/j.carbpol.2018.05.059.

54 T. E. N. Feizi, R. S. Haltiwanger, Current Opinion in Structural Biology 2015, 34, VII-IX 10.1016/j.sbi.2015.10.005.

55 R. G. M. van der Sman, Food \& Function 2017, 8, 360-371 10.1039/C6FO01497F.

56 M. Nagae, Y. Yamaguchi, International Journal of Molecular Sciences 2014, 15, 3768-3783 10.3390/ijms15033768.

57 B. S. Varnamkhasti, H. Hosseinzadeh, M. Azhdarzadeh, S. Y. Vafaei, M. Esfandyari-Manesh, Z. H. Mirzaie, M. Amini, S. N. Ostad, F. Atyabi, R. Dinarvand, International Journal of Pharmaceutics 2015, 494, 430-444 10.1016/j.ijpharm.2015.08.060.

58 S. Hoffmann, C. Gorzelanny, B. Moerschbacher, F. M. Goycoolea, Nanomaterials 2018, 8, 846 10.3390/nano8100846.

59 Y. X. Zhang, Y. R. Xu, X. Y. Xi, S. Shrestha, P. F. Jiang, W. J. Zhang, C. Y. Gao, Journal of Materials Chemistry B 2017, 5, 3521-3530 10.1039/c7tb00344g.

60 I. Alberg, S. Kramer, M. Schinnerer, Q. Hu, C. Seidl, C. Leps, N. Drude, D. Möckel, C. Rijcken, T. Lammers, M. Diken, M. Maskos, S. Morsbach, K. Landfester, S. Tenzer, M. Barz, R. Zentel, Small 2020, 16, 1907574 10.1002/smll.201907574.

61 J. B. Coty, E. E. Oliveira, C. Vauthier, International Journal of Pharmaceutics 2017, 532, 769-778

10.1016/j.jpharm.2017.04.048.

62 D. Bamberger, D. Hobernik, M. Konhauser, M. Bros, P. R. Wich, Molecular Pharmaceutics 2017, 14, 44034416 10.1021/acs.molpharmaceut.7b00507.

63 M. Swierczewska, H. S. Han, K. Kim, J. H. Park, S. Lee, Advanced Drug Delivery Reviews 2016, 99, 70-84 10.1016/j.addr.2015.11.015.

64 S. Z. Fu, J. Y. Xia, J. B. Wu, Journal of Biomedical Nanotechnology 2016, 12, 1585-1603 $10.1166 /$ jbn.2016.2228.

65 V. Mirshafiee, M. Mahmoudi, K. Y. Lou, J. J. Cheng, M. L. Kraft, Chemical Communications 2013, 49, 2557-2559 10.1039/c3cc37307j.

66 K. Pombo-Garcia, C. L. Ruhl, R. Lam, J. A. Barreto, C. S. Ang, P. J. Scammells, P. Comba, L. Spiccia, B. Graham, T. Joshi, H. Stephan, Chempluschem 2017, 82, 638-646 10.1002/cplu.201700052.

67 J. Budhathoki-Uprety, J. D. Harvey, E. Isaac, R. M. Williams, T. V. Galassi, R. E. Langenbacher, D. A. Heller, Journal of Materials Chemistry B 2017, 5, 6637-6644 10.1039/c7tb00695k.

68 M. Papi, D. Caputo, V. Palmieri, R. Coppola, S. Palchetti, F. Bugli, C. Martini, L. Digiacomo, D. Pozzi, G. Caracciolo, Nanoscale 2017, 9, 10327-10334 10.1039/c7nr03042h.

69 Y. Zhu, T. L. Meng, Y. N. Tan, X. Q. Yang, Y. P. Liu, X. Liu, F. Y. Yu, L. J. Wen, S. H. Dai, H. Yuan, F. Q. Hu, Molecular Pharmaceutics 2018, 15, 5374-5386 10.1021/acs.molpharmaceut.8b00842.

70 Y. Y. You, H. Hu, L. Z. He, T. F. Chen, Chemistry-an Asian Journal 2015, 10, 2743-2753

10.1002/asia.201500769. 
71 S. B. Subramaniyan, S. Vijayakumar, S. Megarajan, R. K. Kamlekar, V. Anbazhagan, Acs Omega 2019, 4, 14049-14056 10.1021/acsomega.9b01886.

72 B. Kang, P. Okwieka, S. Schottler, S. Winzen, J. Langhanki, K. Mohr, T. Opatz, V. Mailander, K.

Landfester, F. R. Wurm, Angewandte Chemie-International Edition 2015, 54, 7436-7440

10.1002/anie.201502398.

73 J. Simon, S. Christmann, V. Mailander, F. R. Wurm, K. Landfester, Israel Journal of Chemistry 2018, 58 , 1363-1372 10.1002/ijch.201800166.

74 Y. Yong, R. Su, X. R. Liu, W. N. Xu, Y. F. Zhang, R. Wang, P. K. Ouyang, J. Z. Wu, J. Ge, Z. Liu,

Biochemical Engineering Journal 2018, 129, 26-32 10.1016/j.bej.2017.09.009.

75 H. Tsutsumi, T. Shirai, H. Ohkusa, H. Mihara, Protein and Peptide Letters 2018, 25, 84-89

$10.2174 / 0929866525666171218124434$.

76 Q. Hou, J. E. Wang, X. Liu, X. K. Li, L. N. Ma, W. B. Duan, Z. X. Wang, Chemical Research in Chinese Universities 2012, 28, 947-952.

77 P. J. Muchowskil, Neuron 2002, 35, 9-12 10.1016/s0896-6273(02)00761-4.

78 R. Parveen, T. N. Shamsi, S. Fatima, International Journal of Biological Macromolecules 2017, 94, 386-395

10.1016/j.ijbiomac.2016.10.024.

79 S. Palchetti, D. Pozzi, M. Mahmoudi, G. Caracciolo, Journal of Materials Chemistry B 2016, 4, 4376-4381

$10.1039 / \mathrm{c} 6 \mathrm{tb} 01095 \mathrm{~d}$.

80 C. D. Walkey, W. C. W. Chan, Chemical Society Reviews 2012, 41, 2780-2799 10.1039/c1cs15233e.

81 C. Vidaurre-Agut, E. Rivero-Buceta, E. Romani-Cubells, A. M. Clemments, C. D. Vera-Donoso, C. C.

Landry, P. Botella, Acs Omega 2019, 4, 8852-8861 10.1021/acsomega.9b00460.

82 D. Nierenberg, A. R. Khaled, O. Flores, Reports of Practical Oncology and Radiotherapy 2018, 23, 300-308 10.1016/j.rpor.2018.05.005.

83 M. J. Hajipour, J. Raheb, O. Akhavan, S. Arjmand, O. Mashinchian, M. Rahman, M. Abdolahad, V.

Serpooshan, S. Laurent, M. Mahmoudi, Nanoscale 2015, 7, 8978-8994 10.1039/c5nr00520e.

84 M. Hadjidemetriou, Z. Al-ahmady, M. Buggio, J. Swift, K. Kostarelos, Biomaterials 2019, 188, 118-129

10.1016/j.biomaterials.2018.10.011.

85 M. Magro, M. Zaccarin, G. Miotto, L. Da Dalt, D. Baratella, P. Fariselli, G. Gabai, F. Vianello, Analytical and Bioanalytical Chemistry 2018, 410, 2949-2959 10.1007/s00216-018-0976-z.

86 G. Miotto, M. Magro, M. Terzo, M. Zaccarin, L. Da Dalt, E. Bonaiuto, D. Baratella, G. Gabai, F. Vianello, Colloids and Surfaces B-Biointerfaces 2016, 140, 40-49 10.1016/j.colsurfb.2015.11.043.

87 A. V. Lechuga-Vieco, H. Groult, J. Pellico, J. Mateo, J. A. Enriquez, J. Ruiz-Cabello, F. Herranz,

Nanomedicine-Nanotechnology Biology and Medicine 2018, 14, 643-650 10.1016/j.nano.2017.12.021.

88 L. Zhang, Y. J. Liu, D. X. Yu, N. Zhang, Journal of Biomedical Nanotechnology 2013, 9, 863-869

10.1166/jbn.2013.1584.

89 R. Di Corato, A. Alois, S. Rena, J. M. Greneche, G. Pugliese, T. Pellegrino, C. Malitesta, R. Rinaldi, Acs Applied Materials \& Interfaces 2018, 10, 20271-20280 10.1021/acsami.7b18411.

90 R. Cai, C. Y. Chen, Science Bulletin 2017, 62, 976-977 10.1016/j.scib.2017.07.002.

91 G. M. Mortimer, N. J. Butcher, A. W. Musumeci, Z. J. Deng, D. J. Martin, R. F. Minchin, Acs Nano 2014, 8, 3357-3366 10.1021/nn405830g.

92 E. Ben-Akiva, S. E. Witte, R. A. Meyer, K. R. Rhodes, J. J. Green, Biomaterials Science 2019, 7, 14-30

$10.1039 / \mathrm{c} 8 \mathrm{bm} 01285 \mathrm{~g}$.

93 D. F. Moyano, M. Goldsmith, D. J. Solfiell, D. Landesman-Milo, O. R. Miranda, D. Peer, V. M. Rotello, Journal of the American Chemical Society 2012, 134, 3965-3967 10.1021/ja2108905.

94 F. Shima, T. Akagi, M. Akashi, Bioconjugate Chemistry 2015, 26, 890-898

10.1021/acs.bioconjchem.5b00106.

95 J. Jia, Y. Zhang, Y. Xin, C. Jiang, B. Yan, S. Zhai, Frontiers in Oncology 2018, 8, 404 10.3389/fonc.2018.00404.

96 R. Yang, Y. Zheng, Q. Wang, L. Zhao, Nanoscale Research Letters 2018, 13, 330

10.1186/s11671-018-2759-z.

97 T. H. Kim, H. Jin, H. W. Kim, M. H. Cho, C. S. Cho, Molecular Cancer Therapeutics 2006, 5, 1723-1732 10.1158/1535-7163.mct-06-0540.

98 M. Cuna, M. Alonso-Sande, G. Remunan-Lopez, J. P. Pivel, J. L. Alonso-Lebrero, M. J. Alonso, Journal of Nanoscience and Nanotechnology 2006, 6, 2887-2895 10.1166/jnn.2006.435.

99 J. A. Champion, A. Walker, S. Mitragotri, Pharmaceutical Research 2008, 25, 1815-1821 10.1007/s11095008-9562-y. 
100 Y. Q. Qie, H. F. Yuan, C. A. von Roemeling, Y. X. Chen, X. J. Liu, K. D. Shih, J. A. Knight, H. W. Tun, R. E. Wharen, W. Jiang, B. Y. S. Kim, Scientific Reports 2016, 6, 26269

$10.1038 /$ srep26269.

101 B. Sarmento, D. Mazzaglia, M. C. Bonferoni, A. P. Neto, M. D. Monteiro, V. Seabra, Carbohydrate Polymers 2011, 84, 919-925 10.1016/j.carbpol.2010.12.042.

102 C. C. Toma, A. Aloisi, V. Bordoni, R. Di Corato, M. Rauner, G. Cuniberti, L. G. Delogu, R. Rinaldi, Biomacromolecules 2018, 19, 3560-3571 10.1021/acs.biomac.8b00832.

103 C. C. Chuang, M. H. Tsai, H. J. Yen, H. F. Shyu, K. M. Cheng, X. A. Chen, C. C. Chen, J. J. Young, J. H. Kau, Carbohydrate Polymers 2020, 229, 115403

10.1016/j.carbpol.2019.115403.

104 S. Jesus, E. Soares, G. Borchard, O. Borges, Molecular Pharmaceutics 2018, 15, 72-82

10.1021/acs.molpharmaceut.7b00730.

105 J. Yang, S.-M. Shim, T. Q. Nguyen, E.-H. Kim, K. Kim, Y. T. Lim, M.-H. Sung, R. Webby, H. Poo, Scientific Reports 2017, 7, 44839-44839 10.1038/srep44839.

106 A. Malik, M. Gupta, V. Gupta, H. Gogoi, R. Bhatnagar, International Journal of Nanomedicine 2018, 13, 7959-7969 10.2147/ijn.s165876.

107 A. Malik, M. Gupta, R. Mani, H. Gogoi, R. Bhatnagar, Frontiers in Immunology 2018, 9, 562

10.3389/fimmu.2018.00562.

108 D. A. Zaharoff, C. J. Rogers, K. W. Hance, J. Schlom, J. W. Greiner, Vaccine 2007, 25, 2085-2094

10.1016/j.vaccine.2006.11.034.

109 L. Zhao, A. Seth, N. Wibowo, C. X. Zhao, N. Mitter, C. Z. Yu, A. P. J. Middelberg, Vaccine 2014, 32, $327-$

337 10.1016/j.vaccine.2013.11.069.

110 N. Yakubogullari, R. Genc, F. Coven, A. Nalbantsoy, E. Bedir, Vaccine 2019, 37, 3638-3645

10.1016/j.vaccine.2019.05.038.

111 F. Sarei, N. M. Dounighi, H. Zolfagharian, P. Khaki, S. M. Bidhendi, Indian Journal of Pharmaceutical Sciences 2013, 75, 442-449 10.4103/0250-474x.119829.

112 X. Wang, C. H. Chang, J. H. Jiang, Q. Liu, Y. P. Liao, J. Q. Lu, L. J. Li, X. S. Liu, J. Kim, A. Ahmed, A. E. Nel, T. Xia, Small 2019, 15, 1901642

10.1002/smll.201901642.

113 H. R. Wang, X. Han, Z. L. Dong, J. Xu, J. Wang, Z. Liu, Advanced Functional Materials 2019, 29, 1902440

10.1002/adfm.201902440.

114 S. Narisetty, Faseb Journal 2017, 31.

115 T. Ohta, Cholesteryl Pullulan Nanoparticles-Encapsulated TNF-alpha: An Effective Mucosal Vaccine Adjuvant Against Influenza. Editor, 2016, pp. 139-159. 